“KENS REPORT- VII", edited by N. Watanabe (National Laboratory for High Energy Physics, Tsukuba, $1987 / 88$ ), p.59.

9) K. Suzuki, "Proc. 7 th Inter, Conf. on Liquid and Amorphous Metals, Kyoto, 1989 " to be published in
J. Non-Cryst. Solids.

10）鈴木詳䨋，化学，44，490 (1989).

11) K. Suzuki, J. Non-Cryst. Solids, 95/96, 15 (1987).

12) K. Suzuki, Key Engineering Materials, 13-15, 697 (1987).

2 アモルファス耐食合金および電極材料

橋 本 功 二

1 はじめに

長周期秩序を持たない固相であることを特徵とするア モルファス合金は，平衡状態の固溶限をはるかに越えて 種々の元素を固溶でき，しかす化学的に均一な材料であ る.この特徵は優れた特性を備えた新材料を合金化によっ て作製するのにきわめて適している．特にこのような新 しい材料の化学的性質の研究はまだほとんど行われてい ない未知の限りない魅力を備えた分野である.

\section{2 高耐食合金}

アモルファス合金の化学的性質の研究は，筆者らが初 めて腐食挙動を研究し超耐食性を見出して発表して以来， 世界中で行われるようになっだ．アモルファス $\mathrm{Fe}$ $8 \mathrm{Cr}-13 \mathrm{P}-7 \mathrm{C}$ 合金は, 室温の $2 \mathrm{~N} \mathrm{HCl}$ という激しい 腐食性環境であっても, 自己不锄態化する ${ }^{2)}$. クロム之 モリブデンを同時に添加することは更に有効である.ア モルファス $\mathrm{Fe}-\mathrm{Cr}-\mathrm{Mo}$-半金属合金の中には, $60^{\circ} \mathrm{C} の$ $12 \mathrm{~N} \mathrm{HCl}$ 中でる自己不働態化するものが見出されてい $3^{3)}$.

沸滕濃硝酸の上うな酸化力が高く腐食性の激しい酸中 ではクロムを添加することによって耐食性を得ている合 金はいずれる腐食されるが，タンタルをはじめとするバ ルブメタルを含むアモルファス合金が Fig. 1 に示すよ うに高耐食性を備えている゙）。また共沸組成の沸滕 $6 \mathrm{~N} \mathrm{HCl}^{5)}$, 沸点直下の濃リン酸 ${ }^{6)}$ 中などで金属光沢を 保ち金属タンタルより優れた耐食性を示すアモルファス $\mathrm{Ni}$-Ta 合金などが見出されている.

XPS を用いた筆者らの研究によれば, $1 \mathrm{~N} \mathrm{HCl}$ 中で 自己不動態化したアモルファス Fe-10 Cr-13 P-7 C 合 金に生じた不働態皮膜は $\mathrm{Cr}^{3+}, \mathrm{O}^{2-}, \mathrm{OH}^{-} お$ よび $\mathrm{H}_{2} \mathrm{O}$ からなっていたため, 水和オキシ水酸化クロム不 䣦態皮膜 $\left(\mathrm{CrO}_{\mathbf{x}}(\mathrm{OH})_{3-2 \mathrm{x}} \mathrm{nH}_{2} \mathrm{O}\right)$ 之名付けられた ${ }^{7}$. その後の研究によれば, クロムを含む種々のアモルファ
スおよび結晶質合金に生成する不働態皮膜は，主として， 水和オキシ水酸化クロムから成り，水和オキシ水酸化ク 口ム洤度が高い皮膜ほど, 皮膜の保護性が高い8).

クロムを含む合金に生じた不働態皮膜のクロムイオン

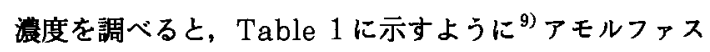
合金は結晶質合金に比へ，有効なクロムイオンを不働態 皮膜中に著しく濃縮できる能力をもっている. 一方，ア モルファス Ni-Ta および $\mathrm{Ni}-\mathrm{Nb}$ 合金のようにタンタ ルあるいはニオブの添加によって耐食性を得ている合金 の皮膜は, 陽イオンが殆ど $100 \% \mathrm{Ta}^{5+}$ あるいは $\mathrm{Nb}^{5+}$ からなる酸化物あるいはオキシ水酸化物からなってい

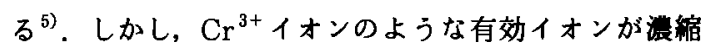
した皮膜が形成してる，皮膜直下の合金組成は合金のバ ルク組成と同じであることが認められている ${ }^{10)}$. した がって, $\mathrm{Cr}^{3+}, \mathrm{Ta}^{5+}$ あるいは $\mathrm{Nb}^{5+}$ イオンのような有 効イオンの灙縮した不制態皮膜の形成は，合金中の皮膜 形成に不要な構成元素の選択溶解の結果である.

不動態化し得る合金の場合，不謿態化に不要な元素が 溶解する活性溶解速度が速いほど，不働態化に有効な元

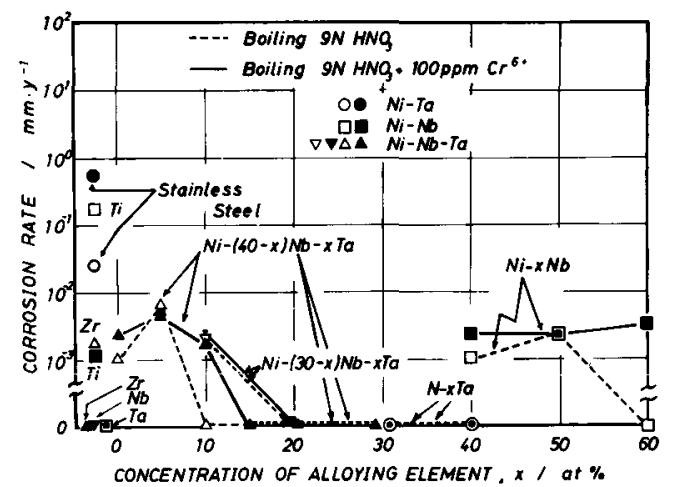

Fig. 1 Corrosion rates of amorphous $\mathrm{Ni}-\mathrm{Nb}$ and $\mathrm{Ni}$-Ta alloys in boiling $9 \mathrm{~N} \mathrm{HNO}_{3}{ }^{4)}$. 
Table 1 Cationic fractions of chromium in the passive films formed on amorphous alloys and stainless steels in $1 \mathrm{~N} \mathrm{HCl}$ at room temperature ${ }^{9)}$.

\begin{tabular}{lcl} 
Alloy & Fraction of $\mathrm{Cr}^{3+}$ in Film & Passivation Procedure \\
Amorphous alloy & & \\
$\mathrm{Fe}-10 \mathrm{Cr}-13 \mathrm{P}-7 \mathrm{C}$ & 0.97 & spontaneous \\
$\mathrm{Fe}-3 \mathrm{Cr}-2 \mathrm{Mo}-13 \mathrm{P}-7 \mathrm{C}$ & 0.57 & anodic polarization \\
$\mathrm{Co}-10 \mathrm{Cr}-20 \mathrm{P}$ & 0.95 & spontaneous \\
$\mathrm{Ni}-10 \mathrm{Cr}-20 \mathrm{P}$ & 0.87 & spontaneous \\
\hline $\mathrm{Ferritic}$ stainless steel & & \\
$\mathrm{Fe}-30 \mathrm{Cr}$ & 0.75 & anodic polarization \\
$\mathrm{Fe}-19 \mathrm{Cr}$ & 0.58 & anodic polarization \\
\hline
\end{tabular}

素が濃縮しやすいので，不郵態化能は合金の活性と関係 が深い, ${ }^{8,11)}$. 熱力学的に準安定で化学的に活性なアモル ファス合金は，皮膜形成に不要な元素を迅速に溶解する ため，不颠態化に有効な元素が著しく濃縮した皮膜を武 速に形成し，自己不働態化の能力が高い。これはアモル ファス合金の高耐食性の一因である.

一方，アモルファス合金にアモルファス母相とは成分 の異なる結晶相が生じると微結晶であってあ著しく不都 態化能が低下する ${ }^{12)}$ ．また結晶質合金に介在物，析出 物などが生じることは避け難いが，合金にこのような化

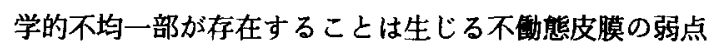
の原因となり，局部的皮膜破壊を引き起こす ${ }^{13)}$ 。これ に対し，化学的に均一なアモルファス合金に生成する皮 膜は，腐食性の激しい環境でもほとんど均一で皮膜破壊 に対して高い抵抗力を備えている．このように，アモル ファス合金の化学的均一性が均一な不䑤龍皮膜の生成を 保証し, 高耐食性之高い不譈態化能の原因の一つとなっ ている.

\section{$3 \mathrm{NaCl}$ 水溶液的解用量極}

海水を冷却水として用いるプラントは生物付着を避け るため, $\mathrm{NaClO}$ を取水口で添加し隇菌を行っている. $\mathrm{NaClO}$ は海水電解によってアノードで生じる $\mathrm{Cl}_{2}$ とカ ソードで生じる $\mathrm{NaOH}$ との反応で得られる.この海水 電解用アノード材料は, 高い酸化条件で発生期の塩素に 曝されるという激しい腐食性条件に耐元, 塩素発生反応 には高い電極触媒活性をすつが競合する酸素発生反応に 対しては不活性でなければならない.Fig.2に一例を 示すように微量の白金族元素を含むアモルファス $\mathrm{Ni}^{-}$ $\mathrm{Nb}$ および $\mathrm{Ni}-\mathrm{Ta}$ 合金は海水相当の浱度の $\mathrm{NaCl}$ 溶液 中でアノード分極すると自己不動態化し高耐食性を示 $す^{14)}$.これらの合金に $1.2 \mathrm{~V}$ (SCE) 付近からみられ る電流密度の急上昇は主として塩素発生反応に基づくも のである、しかしこれらを熄素発生の電極として赛用す るには，活性が 4 析近く低い，そこでニオブ,タンタル

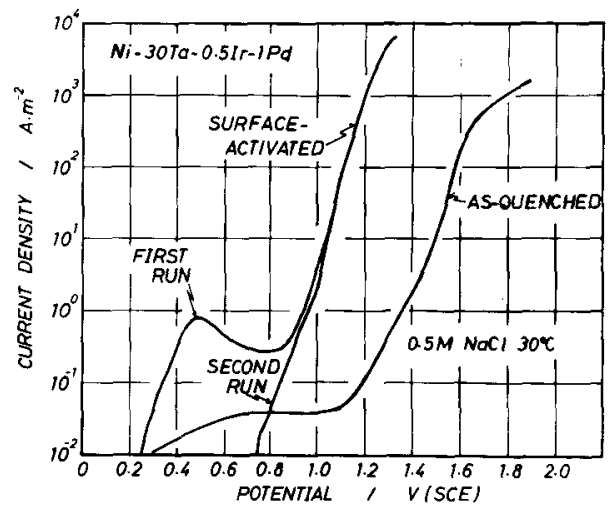

Fig. 2 Anodic polarization curves of amorphous Ni-30 Ta-0.5 Ir-1 Pd alloy measured in $0.5 \mathrm{M} \mathrm{NaCl}$ at $30^{\circ} \mathrm{C}$ before and after surface activation treatment by immersion in $\mathrm{HF}^{14)}$.

などのバルブメタルを溶解するフッ化水素酸にこれらの 合金を浸漬したところ, バルブメタルだけでなくニッケ ルも優先溶解して，有効表面積を增すと共に白金族元素 が表面に浱縮し塭素発生速度が約 4 析増大した.

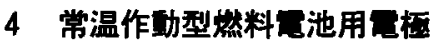

常温で作動するメタノールー空気然料電池が普及しに くい最大の原因は，用いられる白金触媒にメタノール酸 化の中間体が吸着して脱離し難くなるため, 触媒活性が 急激に低下してしまうことであった。これに対しアモル ファス合金という必要ないろいろな元素を添加した均一 固溶体から白金合金触媒を得ることによって，白金の電 子状態を僅かに変えて中間体の結合力を弱めることで長 寿命高活性電極が得られることが期待された，そこで, 钽量の白金族元素を含むアモルファスニッケルーバルブ メタル合金加ら作られる触媒を用い，硫酸溶液中で作動 するメタノールー空気燃料電池用電極が研究された ${ }^{15)}$. 


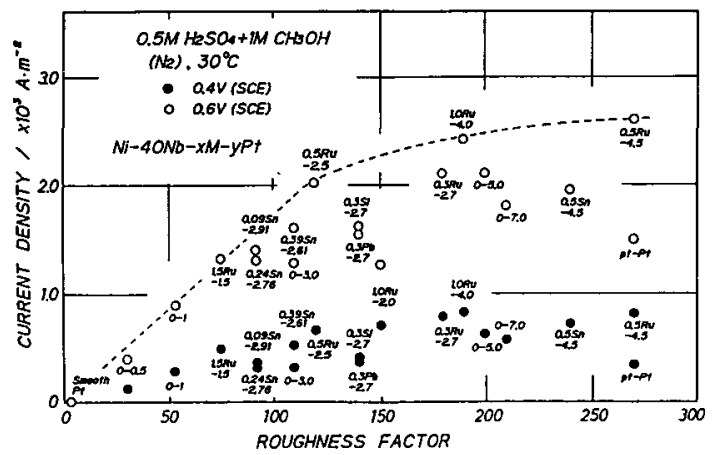

Fig. 3 Current densities of surface-activated amorphous $\mathrm{Ni}-40 \mathrm{Nb}-\mathrm{xM}-\mathrm{yPt}$ alloys for electrochemical oxidation of methanol by potentiostatic polarization in $0.5 \mathrm{M} \mathrm{H}_{2} \mathrm{SO}_{4}+1 \mathrm{M} \mathrm{CH}_{3} \mathrm{OH}^{15}$.

Fig. 3 に示すように，例えば Ni-40 Nb-3 Pt 合金ある いはこの Ptの一部を $\mathrm{Ru}, \mathrm{Sn}, \mathrm{Si}, \mathrm{Pb}$ などで置き換 えた合金に活性化処理を施すと白金黒より高活性な電極 材料が得られる.この知見を基にアモルファス合金から 出発した触媒を用い気体透過性実用電極を試作したとこ ろ，白金黒触媒を用いるより高活性で，燃料極および酸 素極として使用中に活性の低下が起こりにくい電極が得 られた ${ }^{16)}$.

\section{5 化学的特性を活用するための作赀法}

急冷合金の高耐食性を実用に供するには，結晶質実用 金属の表面をアモルファス合金で被覆することが求めら れる. また，電極として用いる場合にも厚さ数 $\mu \mathrm{m}$ 程 度のリボン状合金では，電気抵抗が高く実用には向かな いので，使用環境で侵されない耐食性を備えた電導体金 属を電極特性の優れたアモルファス合金で被覆するなど の方法が求められる.

\section{1 スパッターデポジション}

耐食アモルファス合金をスパッター法で作るとスパッ タ一合金自体の耐食性は十分に高いが，下地に付着させ たまま腐食試験を行うとスパッター合金の欠陥を通して 下地が侵されることがある。このような欠宿は，スパッ ター法に限らず気相から成膜する場合にしばしば生じる あのであって，この克服法を確立することが，気相法に よる耐食被覆実用化の鍵である.

スパッター法がその威力を最も良く発揮するのは，合 金構成元素の一つの融点が他の合金構成元素の沸点より 高く溶融を伴う方法では作製がほとんど不可能な合金で も，合金構成元素の単体を集めた複合ターゲットを用い て合金とすることができ，しかも広い組成範囲でアモル ファス化することである．例えば融点が $2998^{\circ} \mathrm{C}$ の Ta と沸点が $2538^{\circ} \mathrm{C}$ の $\mathrm{Cu}$ からなるアモルファス合金を広

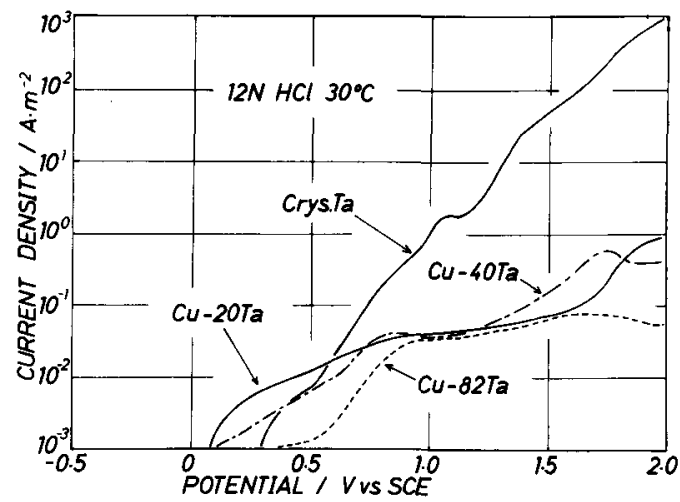

Fig. 4 Anodic polarization curves of amorphous $\mathrm{Cu}-\mathrm{Ta}$ alloys and crystalline tantalum measured in $12 \mathrm{~N} \mathrm{HCl}$ at $30^{\circ} \mathrm{C}^{17}$.

い組成範囲にわたって作製することができ，これらは Fig. 4 に示すように濃塩酸中でも自己不働態化する超 耐食合金である ${ }^{17)}$ 。このほかアモルファス $\mathrm{Al}-\mathrm{Ta}$, $\mathrm{Al}-\mathrm{Nb}$ 合金 ${ }^{18)}$ などの超耐食合金がスパッター法で作製 されている.

\section{2 レーザーおよび霓子ビーム溶急急冷法}

高エネルギー密度ビームであるレーザービームや電子 ビームを照射して局部を瞬間的に溶融すると, 溶湯はま わりの固相に熱を奪われて急冷凝固する.この方法は, 表面を微細化するのにも用いられるが表面の組成を選べ ばアモルファス化することも可能である，適当な表面組 成の場合に，一度レーザービームを照射することにより 溶融した部分が急冷凝固してアモルファス化することは 多くの人々によって認められてきた。しかし，Fig. 5 に示すように，全表面をアモルファス化するには，一度 アモルファス化した部分に一部重ねてレーザービーム照 射を行うことを繰り返さなければならない。このため先 にアモルファス化した部分を加熱することが澼けられず， 熱影噼部が結晶化したり，脆い結晶から亀裂が生じたり する.したがってレーザーを用いる方法はアモルファス 合金を作製する方法の中で最す難しく，アモルファス化 できる表面合金はガラス形成能の極めて高い合金に限定 される，とは言え，組成を選んでレーザー溶融急冷処理 を施すことによって超耐食合金を軟鋼上に作製すること が可能になった ${ }^{199}$.

上述の電解用電極の作製にもこれらの方法が試みられ た. バルフメタルを導電体として徽く下地金属とし，こ れにニッケルと白金族をめっきしたのち，レーザーある いは電子ビーム溶融急冷法を施してアモルファスニッケ ルーバルフメタルー白金族合金をバルブメタルの上に作 ることができた ${ }^{20)}$. 特に電子ビーム処理は有効で，レー ザービーム処理の約百分の一の処理時間で大面積の電極 


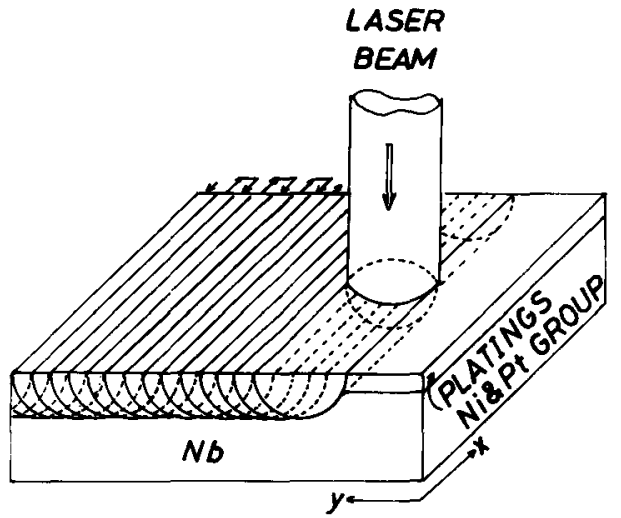

Fig. 5 Schematic drawing of preparation of amorphous $\mathrm{Ni}-\mathrm{Nb}$-platinum group metal surface alloys on niobium by laser treatment.

を作製することができた. Fig.6はこのようにして作 製しフッ化水素酸処理をしたアモルファス合金電極を用 いて塩素発生を行った場合の消費電力を市販電極と比べ たすのである ${ }^{21)}$. 通常の電解条件である $1000 \mathrm{~A} / \mathrm{m}^{2}$ の電流密度でのアモルファス合金電極の消費電力は, 市 販電極の中で最高活性の電極として知られている Pt- Ir $/ \mathrm{Ti}$ 電極のほば $2 / 3$ である。

\section{6 おわに}

アモルファス合金を作ることによって,これまで知ら れていなかった様々な特性を備えた数々の材料が得られ た. 合金中の添加元素の固溶限を拡大させることは特定 の機能を持つ材料を作るためにはきわめて良い方法であ る.これらの化学的性質の研究者はまだ世界でも多くな い. まだ作製の試みがなされていない多くのアモルファ ス合金があり，特に化学的性質は未開拓で，今後新しい 特性を備えた材料が多数見出されるむのと期待される.

\section{文 嗝}

1）奈賀正明，橋本功二，增本 健，日本金属学会誌，38， 835 (1974).

2) K. Asami, K. Hashimoto, T. Masumoto and S. Shimodaira, Corros. Sci. 16, 909 (1976).

3) K. Hashimoto, K. Kobayashi, K. Asami and T. Masumoto, "Metallic Corrosion", Proc. 8 th Int. Cong. Metallic Corrosion, DECHEMA, Frankfurt, 1981, Vol.1, p.70.

4) A. Kawashima, K. Shimamuira, S. Chiba, T. Matsunaga, K. Asami and K. Hashimoto, Proc. 4th Asian-Pacific Corrosion Conference, Tokyo, 1985, Vol.2, p.1042.

5) K. Shimamura, A. Kawashima, K. Asami and K. Hashimoto, Sci. Rep. RITU, A-33, 196 (1986).

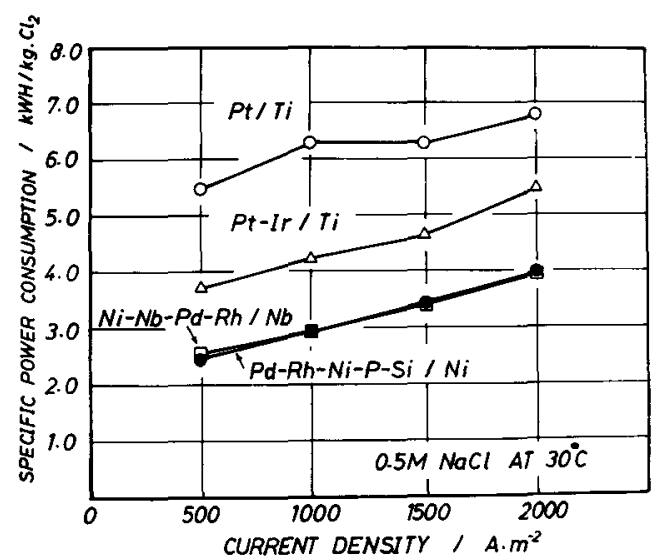

Fig. 6 Specific power consumption of amorphous surface alloys and commercial anodes for chlorine evolution by electrolysis of $0.5 \mathrm{M}$ $\mathrm{NaCl}$ at $30^{\circ} \mathrm{C}^{21)}$.

6) A. Mitsuhashi, K. Asami, A. Kawashima and K. Hashimoto, Corros. Sci., 27, 857 (1987).

7) K. Hashimoto, T. Masumoto and S. Shimodaira, "Passivity and Its Breakdown on Iron and Iron Base Alloys", R. W. Staehle and H. Okada, Eds. National Association of Corrosion Engineers, Houston, Texas, 1975, p.34.

8) K. Hashimoto and K. Asami, "Passivity of Metals", Corrosion Monograph Series, R. P. Frankenthal and J. Kruger, Eds., The Electrochemical Society, Princeton, 1987, p.749.

9) K. Hashimoto, " Passivity of Metals and Semiconductors ", p.235, M. Fromen, Ed., Elsevier, Amsterdam (1983).

10) K. Hashimoto, K. Asami and K. Teramoto, Corros. Sci., 19, 3 (1979).

11) K. Hashimoto, M. Naka, K. Asami and T. Masumoto, Boshoku Gijutsu, 27, 279 (1978).

12) M. Naka, K. Hashimoto and T. Masumoto, Corrosion, 36, 679 (1980).

13) A. Kawashima and K. Hashimoto, Corros. Sci., 26, 467 (1986).

14) N. Kumagai, Y. Samata, A. Kawashima, K. Asami and K. Hashimoto, J. Appl. Electrochem., 17, 347 (1987).

15) A. Kawashima, T. Kanda and K. Hashimoto, Mater. Sci. Engng., 99, 489 (1988).

16) T. Kanda, A. Kawashima, K. Asami and K. Hashimoto, Proc. Symp. Corrosion, Electrochemistry and Catalysis of Metallic Glasses, R. B. Diegle and K. Hashimoto, Eds., The Electrochemical Society, 1988, p.401.

17) K. Shimamura, K. Miura, A. Kawashima, K. Asami and K. Hashimoto, Proc. Symp. Corrosion, Electrochemistry and Catalysis of Metallic Glasses, R. B. Diegle and K. Hashimoto, Eds., The Electrochemical Society, 1988, p.232. 
18) H. Yoshioka, A. Kawashima, K. Asami and K. Hashimoto, Proc. Symp. Corrosion, Electrochemistry and Catalysis of Metallic Glasses, R. B. Diegle and K. Hashimoto, Eds., The Electrochemical Society, 1988, p.242.

19) H. Yoshioka, A. Kawashima, K. Asami and K.
Hashimoto, Corros. Sci., 27, 981 (1987).

20) N. Kumagai, Y. Samata, S. Jikihara, A. Kawashima, K. Asami and K. Hashimoto, Mater, Sci. Engng., 99, 521 (1988).

21) 熊谷直和, 東北大学工学博士学位論文.

3 アモルファス電池材料

山本治

1 はじめに

アモルファス電池材料といえばすぐアモルファス太陽 電池材料がうかぶがアモルファス太陽電池については別 な章で解説されるので本章は化学電池（ガルバニックセ ル）のアモルファス電池材料にかぎって最近の展開につ いて解説する．既存の電池ではとくにアモルファス材料 で重要な役割りをはたしているるのはみあたらないが, 以下に詳説するようにリチウム電池では将来アモルファ ス材料がその性能向上の要となる場合あありうる。 とく に現在その開発がいそがれているリチゥム二次電池では いまだ要求を充分満足する正極材料がみあたらなくその 探索が急務で盛んにアモルファス物質が研究されている. アモルファス材料は等方性, 充放電をくりかえすことに よる形態の変化がおこりにくいこと，さらに結晶性材料 とは異なった表面状態をとうるために特異な性筫が期待 されるのでとくに興味深い材料である. 以下アモルフォ スの電解質および電極について解説する.

\section{2 アモルファス固体軍解兵}

アルカリ金属を負極とする電池はエネルギー密度が高 く軽量化電池として注目されている，負極にリチウムを 用いた電池は一次電池としてすでに実用化されその生産 量は年々増大している．またナトリゥムを負極に，正極 にイオゥを用いた電池は電力眝蔵用として $1,000 \mathrm{~kW}$ 級 のものが実証試験される段陼となっている. 負極にアル カリ金属を用いるさいには水溶液電解質の使用は不可能 で,アルカリ金属と反応しない非水電解質溶液又は固体 電解質を用いる必要がある. エチウム一次電池ではもっ ぱら非水電解質溶液が用いられている.ナトリウム/イ オウ電池ではナトリゥムイオン導電性固体である $\beta-ア$ ルミナが電解質として用いられている，固体電解質 (電 荷担体がイオンである導電性固体）は溶液系電解質と異 三重大学工学部（宁154 津市上洪町）
なり漏液の危険性すなく, 薄膜化す容易でかつ広い温度 範囲での使用が可能といういくつかの長所をもつ.しか し最大の短所は導電率が低い点にある. とくに現在その 開発が最す要望されているリチゥムイオン導電性固体は 水溶液電解質に匹敵する程高い導電率を示するのは報告 されていない. Table 1 に現在報告されている代表的 なリチウムイオン導電性固体を示した。 代表的なりチウ ムイオン導電性固体である LiI の室温での導電率は $10^{-7} \mathrm{~S} / \mathrm{cm}$ と低く電池電解質として用いるさいには薄 膜とする必要がある. 最も信頼性を要求される心䐟ぺー スメーカー用電源にはこの LiI を電解質とした電池が用 いられているが，この場合には釗属りチウムとポリビニ ルピリジンョウ素錯体とを接触させるさいに形成される LiI 薄膜を用いている.この種の電池はセル抵抗（電解 質の抵抗）が高いため高電流密度での放電はできなく汎 用性にかける. $\mathrm{Li}_{3} \mathrm{~N}$ の導電率は室温で, $2.5 \times 10^{-3} \mathrm{~S}$ $/ \mathrm{cm}$ と他の固体電解質に比べて高い導電率を示すが, その分解電圧は $0.44 \mathrm{~V}$ と低くリチウム電池用電解質に は適しない，特記すべき点は， $\mathrm{Li}_{2} \mathrm{~S}-\mathrm{LiI}-\mathrm{B}_{2} \mathrm{~S}_{3}$ ガラ スの導電率が室温で $1 \times 10^{-3} \mathrm{~S} / \mathrm{cm}$ 之高いことである.

最近アモルファス（ガラス）リチウムイオン導電性固 体電解質に関する研究が盛んである. イオン蔡電性ガラ スに関する最初の報告は $\mathrm{Ag}^{+}$イオン導電体である ${ }^{1)}$. Minami 等は2 ${ }^{2)} \mathrm{AgI}-\mathrm{AgI}_{2} \mathrm{MoO}_{4}$ ガラスと, その結晶 相との室温における導電率を測定した結果, ガラス形成 全組成範囲でガラス相が結晶相に比して 1 2 析程導電 率が高いと報告している. Fig. 1 に $\mathrm{Ag}^{+}$イオン導電性 ガラスの導電率の温度変化を示した. 図中 $\mathrm{AgI}-\mathrm{Ag}_{4}$ $\mathrm{P}_{2} \mathrm{O}_{7}$ ガラスは室温で $2 \times 10^{-2} \mathrm{~S} / \mathrm{cm}$ と高い導電率を示 すことがうかがえるが，この系では AgI 80 モル\%の組 成で中間化合物 $\mathrm{Ag}_{19} \mathrm{I}_{15} \mathrm{P}_{2} \mathrm{O}_{7}$ が存在しその結晶相の導 電率は $\mathrm{AgI}-\mathrm{Ag}_{4} \mathrm{P}_{2} \mathrm{O}_{7}$ ガラスと同様室温で $2 \times 10^{-2} \mathrm{~S}$ $/ \mathrm{cm}$ の導電率を示す ${ }^{3)}$. 従ってガラス相が常に結晶 